\title{
Some Aspects of Countering the Extremist Ideology in the Russian Regions
}

\section{Diana Pirbudagova}

\author{
Federal state budget-funded educational institution of higher professional education Dagestan state university \\ 43-a Magomed Gadzhiyev Str., Makhachkala, the Republic of Dagestan, Russia, 367000, kafedraconst@mail.ru
}

\section{Zaira Musalova}

Federal state budget-funded educational institution of higher professional education Dagestan state university 43-a Magomed Gadzhiyev Str., Makhachkala, the Republic of Dagestan, Russia, 367000, kafedraconst@mail.ru

\section{Doi:10.5901/mjss.2015.v6n6s5p122}

\begin{abstract}
In the paper, the authors attempt to consider some economic and legal aspects of preventing and countering extremism in the Russian Federation. Approaches to understanding of extremism, its forms as a whole, causes of its spread and methods to be used to counter the spread of extremist views have been investigated. Influence of social and economic factors on the extremist ideology spread in Russia has been studied. Some problems of the extremist ideology spread in Russia have been considered from various viewpoints. By analyzing the existing approaches to solving the issues under consideration as well as the results of a survey carried out among the population of the Republic of Dagestan, as one of the most unstable in this context, constituent entities in the North Caucasus, the authors have made a number of conclusions regarding the causes, conditions, factors of the extremist views spread and efficiency of countering methods. The paper focuses on the regional aspect of extremism countering organization in the territory of the Russian Federation; moreover, the possibility to involve public institutions in this process on the basis of positive experience gained by some Russian constituent entities is investigated. In particular, the analysis subjects were adaptation commissions which had been created in some entities of the North Caucasus.
\end{abstract}

Keywords: constitution, ideology, extremism countering, causes, law.

\section{Introduction}

Nowadays, in the Russian Federation, despite the general constitutional principles of regulation established in the Constitution of the Russian Federation of 1993, the ideological sphere is still quite unstable, contradictory, it is one of the factors determining the content and rate of development of the political, social and economic, and cultural spheres of the social life of the country. One of the negative manifestations of the current state of the ideological processes in Russia is the extremist views spread, being a serious threat to the security of the State and its integrity preservation. According to the law enforcement authorities, activities of the extremist structures and illegal armed groups as a major threatening factor in the public security significantly influence on the crime situation. However, it should be noted that the number of terrorist crimes has decreased; this may demonstrate more efficient work of the law enforcement authorities, though at the last stage of the extremist organizations' activities. This fact again proves the need to strengthen efforts to warn, prevent and suppress extremism and, particularly, the extremist views spread among the population.

\section{Literature Review}

The concept of extremism. As for the definition of extremism, in its most general form, it should be understood as commitment to extreme measures and views, strive to solve problems and achieve goals using the most radical methods, including all kinds of violence and terror. Peter Coleman (International Center for Cooperation and Conflict Resolution at Columbia University), and Andrea Bartoli (Institute for Conflict Analysis and Resolution of at George Mason University) define extremism as all kinds of activities (views, attitudes, feelings, actions, strategies), which differ from conventional ones (P.T. Coleman and A. Bartoli). Thus, any extremist views are based on absolute rejection of other ideological beliefs.

The forms of extremism. There are different positions concerning the extremism forms and types. L. Wilcox and J. 
George in their research distinguish two main types of extremism in the United States: left and right (J. George, L. Wilcox, 1992). According to the authors, Communist parties referred to the left extremists, and various neo-Nazi organizations to the right. At the same time, S.M. Lipset, in particular, argued that, along with the right and left extremism, there is extremism of the Center, on which basis fascism was formed (Lipset S.M., 1960). Such positions are typical for the second half of the XX century as the "cold war" consequences. In addition, this differentiation reflects the essence of a political form of extremism in a very limited way (Eatwell R., 2003).

The causes of the extremist views spread. Various authors identify different causes of the extremism spread. D. Olshansky, for example, identifies the following main causes of the extremist ideology emergence:

- social and economic factors, including a drop in the populations' living standard;

- negative manifestations of political institutions and governmental structures, their inability to solve urgent problems of the social development;

- totalitarian nature of the political regime, absence of a real opposition, persecution of dissent, violation of national feelings, strive of certain groups to speed up their problems solution, leaders' political ambitions, etc. (D. Olshansky, 2002)

While considering the causes of the youth extremism emergence and development in the Russian Federation, E.A. Pain specifies the following ones:

- different kinds of the social injustice;

- deterioration of the financial situation of this population category;

- violation of the youth' rights, discrimination and a limited form of their protection, etc.

According to the author, these causes prove that the main problems caused by various protest forms of the youth's self-organization are social injustice, violation of the young citizens' economic and constitutional rights (E.A. Pain, 2002).

The influence of the social and economic factors on the extremist views spread is indirectly confirmed by the fact that it has been spread mostly in the countries with a low level of the social and economic development.

According to Walter Laqueur, the main myth of terrorists is that they are poor, hungry and deprived of human desires. At the same time, it is primarily the case of the extremist organizations leaders; for example, officials of the Palestine Liberation Organization receive 5,000 dollars a month, and the total income of the organization is 150-200 mln. dollars a year (L. Walter, 1978). It is not by mere chance that in a number of common positions of the EU Council concerning the measures to counter extremism and terrorism, they specify the need to limit financing of extremist and terrorist organizations, particularly, to freeze financial assets, for example, in the Common Position dated December 27 , 2001 "On Combating Terrorism" (The Memorandum, 2001).

Along with some of the above-mentioned causes of the extremist views emergence and spread, E.L. Zabarchuk, also emphasizes "migrants' influx, ethnic crime" (E.L. Zabarchuk, 2008).

S.N. Fridinsky notes that the extremist crime growth is greatly affected by the social tension aggravation in the country, decrease in the employment rate and other factors criminalizing the society (S.N. Fridinsky, 2006).

Apart from the extremism growth causes, the author classifies three groups of factors, including economic, i.e. economic crises, unemployment, impoverishment of the majority of the population, criminalization of a certain part of the economy; great social stratification in the society; the second group of factors - social and political, i.e. the government weakening and its force structures inactivity; high corruption of officials; criminalization of the society; assistance to extremists from the representatives of the foreign non-governmental organizations channeling money to finance the extremist activity; the third group - ideological factors, i.e. lack of a national recognized ideological concept shared by the overwhelming majority of the population.

The general analysis of the different positions concerning the causes of the extremist views emergence shows that despite the variety of approaches, almost all authors emphasize the social and economic factor of the extremism spread. According to M.A. Yavorsky, "the causes of the extremism development and spread in the society, as well as opinions and approaches to its understanding, have many aspects, but the main determinants of extremism and most wrongful acts have been social and economic causes expressed in the social injustice accumulating many other circumstances "(M.A. Yavorsky, 2008).

According to A.V. Sergeeva, one of the most significant potential causes of emergence and development of extremist views and all their manifestations are social and economic factors, and they are directed both against the individual and the State and the society as a whole (A.V. Sergeeva, 2010).

According to N.D. Makhmadiev, extremism is a social deterministic phenomenon which has particular prerequisites for its emergence and specific conditions of its existence, which are deterioration of the social and political, economic and psychological conditions of the social life (N.D. Makhmadiev, 2012). 
Factors reducing the extremist views spread in Russia. According to I.N. Senin, to solve the problem of the extremism spread in Russia, it is necessary to effect qualitative changes in the social situation, in addition to the legislative measures. According to the author, for this purpose, "it is necessary to ensure real improvement in the population's living standard, by greatly reducing its social stratification; achieve a high level of moral and legal culture of the individual and society; create an efficient youth's socialization system enabling them to perform self-fulfillment "(I.N. Senin, 2011).

In most cases, the key methods of combating various extremism manifestations are the force methods based on the activities of various law enforcement authorities of the State. At the same time, according to V.N. Lopatin, to organize countering the extremist phenomena, it is necessary "to use not only force methods, but to a greater extent, appropriate legal and economic tools supported by social and psychological and ideological measures aimed at limiting negative conditions and corruption prerequisites" (Lopatin, 2001). One of the areas of countering extremism is aimed at eliminating its emergence causes. However, there is no clear understanding of this issue.

\section{Research Methods}

We used general scientific methods (logical, systematic, functional, etc.); specific scientific methods (formal legal, comparative legal, case study method, modeling method, statistical, etc.), method of constitutional comparativistics, constitutional interpretation.

\subsection{Empirical Methods}

Within the framework of this study, a poll was carried out; the poll purpose was to determine the attitude of the population of the Republic of Dagestan - a constituent entity of the Russian Federation, one of the most problematic regions in the North Caucasus in the context of countering extremism, to this phenomenon and the extremism countering measures implemented by the federal and republican governmental authorities. The poll was conducted in April and March 2015. 250 persons of different age groups (from 18 to 70 years), different social status, educational level were polled. Questions and variants of answer were given in accordance with Table 1.

Table 1. Questionnaire

\begin{tabular}{|c|c|c|}
\hline No. & Question & Variants of Answer \\
\hline 1. & $\begin{array}{l}\text { Which form of extremism is, in your opinion, the most threatening in Russia? } \\
\text { (choose one of the answers) }\end{array}$ & $\begin{array}{l}\text { 1. National } \\
\text { 2. Religious } \\
\text { 3. Social } \\
\text { 4. Other (write in) } \\
\end{array}$ \\
\hline 2. & $\begin{array}{l}\text { The Russian authorities can protect the population of Russia from new } \\
\text { terrorist attacks, can't they? (choose one of the answers) }\end{array}$ & $\begin{array}{l}\text { 1. Definitely, yes } \\
\text { 2. Rather, yes } \\
\text { 3. Rather, no } \\
\text { 4. Definitely, no } \\
\text { 5. Neither agree nor disagree }\end{array}$ \\
\hline 3. & $\begin{array}{l}\text { In your opinion, what changes occurred in recent years in combating } \\
\text { extremism? (choose one of the answers) }\end{array}$ & $\begin{array}{l}\text { 1. The situation has significantly improved } \\
\text { 2. The situation has slightly improved } \\
\text { 3. The situation has not improved } \\
\text { 4. The situation has slightly worsened } \\
\text { 5. The situation has significantly worsened } \\
\text { 6. Neither agree nor disagree }\end{array}$ \\
\hline 4. & $\begin{array}{l}\text { The activities of the federal government authorities in countering extremism } \\
\text { are efficient, aren't they? (choose one of the answers) }\end{array}$ & $\begin{array}{l}\text { 1. Definitely, yes } \\
\text { 2. Rather, yes } \\
\text { 3. Rather, no } \\
\text { 4. Definitely, no } \\
\text { 5. Neither agree nor disagree }\end{array}$ \\
\hline 5. & $\begin{array}{l}\text { The government authorities in the constituent entities of the Russian } \\
\text { Federation have real powers to counter extremism, don't they? (choose one } \\
\text { of the answers) }\end{array}$ & $\begin{array}{l}\text { 1. Definitely, yes } \\
\text { 2. Rather, yes } \\
\text { 3. Rather, no } \\
\text { 4. Definitely, no } \\
\text { 5. Neither agree nor disagree }\end{array}$ \\
\hline
\end{tabular}




\begin{tabular}{|c|c|c|}
\hline 6. & $\begin{array}{l}\text { Rate the quality of the Russian laws in countering extremism? (choose one } \\
\text { of the answers) }\end{array}$ & $\begin{array}{l}\text { 1. Excellent } \\
\text { 2. Good } \\
\text { 3. Satisfactory } \\
\text { 4. Unsatisfactory } \\
\end{array}$ \\
\hline 7. & $\begin{array}{l}\text { What is, in your opinion, the reason for the extremism spread in Dagestan? } \\
\text { (write in any number of answers) }\end{array}$ & \\
\hline 8. & $\begin{array}{l}\text { What is, in your opinion, the reason for the extremism spread in Dagestan? } \\
\text { (write in any number of answers) }\end{array}$ & \\
\hline 9. & $\begin{array}{l}\text { How do you estimate the activities of the Adaptation Commission in the RD? } \\
\text { (choose one of the answers) }\end{array}$ & $\begin{array}{l}\text { 1. It is an efficient mechanism to counter } \\
\text { extremism } \\
\text { 2. In some cases, such institutions produce } \\
\text { positive results } \\
\text { 3. In general, satisfactory } \\
\text { 4. Its activities have a negative impact on } \\
\text { countering extremism in the RD } \\
\end{array}$ \\
\hline 10. & $\begin{array}{l}\text { What is the role of the civil society institutions (for example, the Public } \\
\text { Chamber, Soldiers' Mothers' Committee, etc.) in countering the extremism } \\
\text { spread? (choose one of the answers) }\end{array}$ & $\begin{array}{l}\text { 1. It is an efficient mechanism to counter } \\
\text { extremism } \\
\text { 2. In some cases, such institutions produce } \\
\text { positive results } \\
\text { 3. In general, satisfactory } \\
\text { 4. Its activities have a negative impact on } \\
\text { countering extremism } \\
\end{array}$ \\
\hline 11. & $\begin{array}{l}\text { Your actions, if you become aware of the facts of extremist activity } \\
\text { manifestations }\end{array}$ & $\begin{array}{l}\text { 1. I will appeal to the law enforcement } \\
\text { authorities. } \\
\text { 2. I will consult my relatives. } \\
\text { 3. I will not respond in any way, if it does not } \\
\text { concern me. } \\
\text { 4. I will not appeal to anywhere, because it } \\
\text { may threaten my safety. }\end{array}$ \\
\hline 12. & In your opinion, what factors can help reduce extremism in Russia? & $\begin{array}{l}\text { 1. Improving the population's welfare. } \\
\text { 2. Reducing the unemployment rate. } \\
\text { 3. Improving efficiency of the law } \\
\text { enforcement authorities. } \\
\text { 4. Improving the inter-ethnic relations. } \\
\text { 5. Strengthening control of the government } \\
\text { authorities over the activities of religious } \\
\text { institutions. } \\
\text { 6. Your answer. }\end{array}$ \\
\hline
\end{tabular}

\section{Results and Discussion}

First of all, it should be noted that the vast majority of the respondents indicated religious and national extremism forms $(80 \%)$ as the most threatening in Russia. What concerns the authorities' ability to protect the population of Russia from new terrorist attacks, in the respondents' opinion, it is very doubtful, most answers were "Rather, no" (40\%) or "Definitely, no" (37\%). A negative perception was reflected in the answer to the question concerning changes that occurred in recent years in combating extremism, the majority of respondents answered that the situation has worsened (38\%), or the situation has not changed (25\%).

Generally, the results of sociological survey conducted show lack of the population's support of the measures taken by the State, both at the federal and regional levels, in countering extremism.

The situation paradox is that, when estimating efficiency of the federal authorities' activities in countering extremism, the respondents' opinions were almost equally divided (44\% - positive answers, 50\% - negative ones). Similarly, answers to the question concerning the real powers of the government authorities in the constituent entities of the Russian Federation in countering extremism (46\% - positive answers, 49\% - negative ones). Moreover, estimation of the quality of the Russian laws in countering extremism was satisfactory (55\%).

What makes uneasy is when answering the question concerning actions, if it is known about the facts of extremist activity manifestations, the greatest number of answers were "I will address to the law enforcement authorities" (32\%) and "I will not address to anywhere, because it may threaten my safety" (36\%).

As for the extremism spread causes, the following factors were most frequently named: 


\author{
"Outside forces" effect, foreign countries' interest (17\%). \\ Low educational level (15\%). \\ International conflicts (14\%). \\ Corruption (13\%). \\ Inefficient activities of the law enforcement authorities (13\%). \\ Recruitment (10\%).
}

It should be noted that among the causes of the extremist ideology spread an economic factor was named rather rarely (only 11\%), though the North Caucasus republics, for which these problems are very acute, as a rule, are significantly inferior to other constituent entities of Russia in the social and economic development level.

At the same time, an economic factor was most often named among the factors that can contribute to reducing extremism in Russia. The most common answers were reducing the unemployment rate (20\%) and improving the population's welfare (22\%). Regarding measures for countering extremism, as a whole, and extremist views, in particular, the following factors were named: improving efficiency of the law enforcement authorities (23\%), improving the interethnic relations (22\%), strengthening control of the government authorities over the activities of religious institutions (20\%).

In this situation, it is particularly important to involve civil society institutions, non-governmental organizations and religious institution in solving this problem.

In a number of constituent entities of the Russian Federation, including Southern and North Caucasian Federal District, social structures aiming at improving inter-religious and inter-ethnic trust, are supported. Such organizations exist in each region, and their importance can hardly be overestimated ("Union of Stavropol Peoples for Peace in the Caucasus", "The Supreme Council of the Ossetians", etc.). Moreover, in each constituent entity of the Russian Federation there are their own unique projects. Thus, over the last few years the Anti-Terrorist Commission (ATC) in the Kabardino-Balkar Republic has been implementing an interregional youth project "Kunachestvo"; within the project, different public events in which children from the North Caucasus republics participate, are organized. In the Republic of North Ossetia-Alania, "Peace to the Children of the Caucasus" Project has been implemented with an active support of the national cultural center "Nykhas"; within the project, "friendship visits" of pupils from neighboring countries are organized.

The experience gained by a number of republics of the North Caucasian Federal District is worth noting in creation and operation of various kinds of commissions aiming at adaptation of the persons once involved in the extremist activities.

The above-mentioned commissions, as a rule, consist of the representatives of the government authorities of the Russian Federation, law enforcement authorities, regional non-governmental organizations, religious institutions. Due to the fact that the experience of this kind of commissions is rather small, still there is no clear understanding of the functions which are assigned to the commission as a whole and to each of its members individually. A lot of skeptical remarks were made immediately after the institution creation. And they are still being expressed. The main argument in the criticism is the fact that the commission can not provide real security guarantees. Once, the Head of Ingushetia acted as such a guarantor by himself. On October 22, 2012 a "hot line" of the Head of the Republic of Ingushetia for members of illegal armed groups who wish to return to a peaceful life, started to work. In Dagestan, for a short period of time 20 people were drawn from the criminal underworld. These data were announced at the first meeting of the commission with the Head of the Republic for reconciliation and harmony, which was established after abolition of the Adaptation Commission, despite the positive role of this institution.

\title{
5. Conclusion
}

It is obvious that in modern Russia the extremist views spread is a real threat to stability, national security and social and economic development of the country. The experience gained in a number of countries (Libya, Syria, Iraq) shows that extremism can be well organized, sufficient to break the territorial integrity of the country. According to the data provided by the official sources in Syria, thousands of Russians, most from the North Caucasus, fight for "Islamic State of Iraq and the Levant".

In these circumstances, it seems necessary to study mechanisms to counter the extremist views spread in our country; a particular attention should be paid to the North Caucasus republics, as the most dangerous region in this context.

In this way, it is necessary to use both state and non-state mechanisms, actively involve non-governmental 
organizations, civil society institutions. Nowadays, the regional adaptation commissions play a significant role in countering the terrorism and extremism spread, they are an additional tool through which fighters return to a peaceful life.

It should be noted that without solving the social and economic problems, including improving the population's living standards, reducing the unemployment rate, improving the educational level, including a legal aspect, etc., prerequisites for the extremism emergence and manifestations in various forms, including national and religious ones, will be preserved in our country, that will definitely affect not only the social and economic development of Russia, in general, but political stability in the country. Moreover, we should not forget about the need to form a Russian uniform ideological concept shared by the majority of the population, regardless of self-identification and religious components.

\section{Acknowledgements}

The study was carried out as per the state order of the Ministry of Education and Science of Russia in the scientific activities; project No. 2014/33 "Integrated Study of the Extremism and Terrorism Ideology in Dagestan".

\section{References}

Coleman, P.T. Addressing Extremism

http: www.tc.columbia.eduli/a/document19386_WhitePaper_2_Extremism_030809.pdf.

Eatwell, R.A. (2003)Spectral-Syncretic Approach to Fascism. The Fascism Reader. Ed. A.A. Kallis. L.: Routledge, 2003, 79-80.

Fridinskiy, S.N. (2006). Nekotorye problemy protivodeistviya ekstremizmu v Rossiyskoi Federatsii [Some Problems of Countering Extremism in the Russian Federation] // Pravo i bezopasnost' [Law and Security], No. 1, 70.

George, J. (1992). Nazis, Communists, Klansmen, and Others on the Fringe: Political Extremism in AmericaJ. N.Y.: Prometheus Books.

Laquer W. (1978). Terrorism - A Balance Sheet. The Terrorism Reader: A Historical Anthology. Edited by Walter Laquer. Philadelphia, 251-267.

Lipset, S.M. (1960). Political Man. Garden City, N.Y.: Doublesday.

The Memorandum "Antiterrorism" (2001). Maastricht Journal of European and Comparative Law, Vol 21, №3, 17.

Lopatin V.N. (2001). O sistematicheskom podkhode v antikorruptsionnoi politike [On the Systematic Approach to Anti-Corruption Policy]. Gosudarstvo i pravo, No. 7, 29.

Makhmadiev, N.D. (2012). Sotsial'nie korni relighioznogo ekstremizma v Tadjikistane [The Social Roots of Religious Extremism in Tajikistan]. Thesis Abstract. Candidate of Legal Sciences. Dushanbe.

Olshansky, D. (2002). Psikhologiya Terrora [Psychology of Terror]. Yekaterinburg: Acad.project: OPPL: Business Book.

Pain E.A. (2002). The Social Nature of Extremism and Terrorism. Social Sciences and Modernity, No. 4, 121.

Senin, I.N.. Extremism as a Form of Legal Nihilism in Modern Russia (Theoretical and Legal Aspect): Thesis Abstract. Candidate of Legal Sciences. Saratov.

Sergeeva, A.V. (2010). K voprosu ob ekonomicheskikh faktorakh rosta ekstremizma sovremennoi Rossii [On the Economic Factors of Extremism Growth in Modern Russia]. Rossijskiy sledovatel' [Russian Investigator], No. 16, 39.

Yavorsky, M.A. (2008). Prichiny i usloviya proyavleniy religioznogo ekstremizma [The Causes and Conditions of Religious Extremism in Modern Russia]. Yuridicheskiy Mir [Legal World], No. 11, 24.

Zabarchuk, E.L. (2008). Relighiozniy ekstremizm kak odna iz ugroz bezopasnosti rossiyskoi gosudarstvennosti [Religious Extremism as one of the Threats to the Security of the Russian Statehood]. Journal rossiyskogo prava, No. 6, 6. 